\title{
Examining the Teachers' Emotional Labor Behavior
}

\author{
${ }^{1}$ Siirt University, Turkey. \\ Rasim Tösten ${ }^{1}$, Çiğdem Çelik Şahin ${ }^{2}$ \\ ${ }^{2}$ Adana Science and Art Center, Turkey. \\ Correspondence: Rasim Tösten, Siirt University, Turkey.
}

$\begin{array}{lrr}\text { Received: July 4, } 2017 & \text { Accepted: August 20, } 2017 \quad \text { Online Published: August 24, } 2017 \\ \text { doi:10.11114/jets.v5i10.2621 } & \text { URL: https://doi.org/10.11114/jets.v5i10.2621 }\end{array}$

\begin{abstract}
The aim of this research is to investigate the teachers' emotional labour behaviours and to determine the reasons of the differences. In the research, mixed research methods including both quantitative and qualitative techniques were used. The population of the study was comprised of 280 teachers (266 for quantitative, 14 for qualitative dimensions) who work in Siirt city center. Because of the difficulties to reach the target population, time limitations and the cost over run, representative sampling was preferred. In order to investigate the teachers' emotional labour behaviors, "Emotional Labour Behaviors Scale" which was adapted by Kaya (2009) was administered to the teachers in the study. This scale was adapted for educational field. For the quantitative dimension of the research, 266 scales were analysed by using percentage, means, frequency and standard deviation for descriptive statistical techniques. T-test, ANOVA tests were used for the differences among the variables. As a result of the research, findings indicated that there were significant differences in the teachers' emotional labour behavior scores. The significant differences were found in the scores of the number of teachers, the working time at schools, the type of graduated faculty, and the type of the school. The questions related to the qualitative dimension of the research were asked to the teachers with different branches and gathered data were analysed using content analysis technique. According to the participant teachers opinions, the reasons for the significant differences of emotional labour behavior scores are different occupational definitions, being ready for the teaching profession, exhibiting more efforts and interest, more close relationships, and the negative effects of staying much more at school on the teachers. The participant teachers expressed their solutions as solving the teachers' time and place problems, constituting more imteractive relationships among students and colleagues and preparing effective working schedule.
\end{abstract}

Keywords: emotional labor, teachers, behaviours

\section{Introduction}

The emotional labour term was firstly used by Hochschild in 1979 in the meaning of deliberately hiding or expressing the emotions of meeting the organizational aims (Cited by Brown, 2011). According to Morris and Feldman, the emotional intelligence is to display the behaviors which are desired by the organizationsin interpersonal relationships (Morris and Feldman, 1996). In other words, the emotional labour concept is to exhibit the emotions which are desired in mutual relationships (Robbins, 2005, 114).

The emotional labour is in the natural process of working, so that, the skills for regulating the emotions have been needed for the professional effectiveness (Sutton, 2004 cited by Kinman et al., 2011). Winograd (2003) explained that teaching needs different kinds of behavioral rules. It may be explained that teachers who exhibit the emotinal labour behaviors mostly ignore these rules (Cited by Çukur, 2009). Accordingly, in the professional process, it will contribute to realization of organizational aims to find out what the emotional labour is and how it is shaped.

The emotional rules which are affected by the sociocultural background of teachers and educational practices have based upon the organizational aims and help the teachers to reach the teaching goals. The teachers should approach to the parents of the students with the feelings of interest, keeping promises, being respectful, emphathy, accepting and expressing the suggestions calmly (Liu, 2012). And all of these may be accepted as indicators of emotional labour.

It has been long known that emotional labour has positive or negative effect to realize the organizational purposes. Xiao (2012) emphasized the close relationship between the Professional performance and emotional labours. In the same research, the negative relationship at expressing superficial behavior dimension was found; there was found positive 
relationship between the deep action and expressing naturally felt emotions (Cited by Ye and Chen, 2015).

The teaching profession always needs to have higher degree of emotional labour behavior, because of that, it has been known the teachers are under the risk of emotional burn out. The national educational organizations should develop motivational studies to reduce the negative emotional labour behavior level, and find effective solutions (Basim, Beğenirbaş ve Can Yalçın, 2013).

The focal point of the researches related to the emotional labour is how the teachers exhibit the expected emotional labour behaviors. The personnels follow three steps: surface acting, deepacting and genuine emotion (Diefendorf, vd., 2005: 243; Ashforth ve Humphrey, 1993: 90). Surface acting is to pretend to feel and emotion showing facial expressions like gestures, mimics, and voice. This doesn't mean that the personnel doesn't feel anything, the real feelings diffeentiate from the reflected feelings (Chu ve Murrmann, 2006: 1182; Ashforth ve Humphrey, 1993: 92-93; Ye ve Chen, 2015). Deep acting is that the person tries to honestly feel the emotions which are being expected. Here, the feelings are actively encouraged, shaped or supressed. Genuine emotions express the behaviors that naturally presented. It is also possible to express genuine emotions as natural behaviors.

Lihua Miu (2009) developed the Scale of Teachers' Emotional Labor which has satisfying reliability and validity and defined emotional labour behaviours as four dimensions for secondary school teachers. These are deliberative dissonance action, surface acting, deep acting and expression of naturally felt emotions (Liu, 2009). Yuxian Xu' study (2012) found the teachers use of surface acting more than deliberative dissonance acting (Xu, 2012).

Some studies found that surface acting had positive prediction function on emotional exhaustion, deep acting and expression of naturally felt emotions had negative prediction function on it (Basim, \& Begenirbaş, 2013; Zhang, 2013; Tian et al., 2009).

\subsection{The Aim of the Study}

The main aim of this study is to examine the emotional labour behaviors with regards to the different variables and to find answers to these questions:

1) What are the emotional labour behaviour levels of the teachers?

2) Is there a significant difference in emotional labour behaviour according to the sex, number of the teachers at school at which they work, working hours at schools, age, professional seniority, graduate degree and type, salary satisfaction and school type?

3) What are the reasons of the significant differences of the emotional labour behaviors of the teachers among the variables?

4) What are the teachers' solution suggestions to strengthen the emotional labour behaviors?

\section{Methodology}

The mixed method including quantitative and qualitative approaches were used together in this research. A mixed methods study is research intentionally combining orintegrating quantitative and qualitative approaches as components of the research. The use of these approaches can occur at different points in the research process (Caruth, 2013; Teddlie and Tashakkori, 2009; Greene, 2007).

a. In the planning phase where the research plan is developed, it becomes clear what is investigated and how quantitative and qualitative approaches are used.

b. Combining or integrating research questions from quantitative and qualitative approaches to guide the researcher into the complexity of the problem studied.

c. Using quantitative measurement instruments with qualitative research techniques to generate quantitative and qualitative data for the research problem.

d. Combining or integrating quantitative and qualitative data in the analysis of study data.

e. Combining or integrating quantitative and qualitative data in the presentation of the study findings on some assumptions about what research is and how it should develop. When the researcher combines or integrates quantitative and qualitative approaches in the design of mixed study, what it does is create a third research model that allows using these two in an articulated and harmonic manner. The first step to combine orintegrate quantitative and qualitative approaches in the same study is to understand the assumptions, the foundations and characteristics of mixed studies, as a third research model (Caruth, 2013). 


\section{The Study Group of the Research}

The study was conducted in Siirt and the study group was consisted of 280 teachers who work in the city center of Siirt. The study group was chosen according to the random sampling.

Table 1. The characteristics of the participant teachers in quantitative research process

\begin{tabular}{|c|c|c|c|}
\hline & & $\boldsymbol{F}$ & $\%$ \\
\hline \multirow{3}{*}{ Sex } & Female & 96 & 36,1 \\
\hline & Male & 170 & 63,9 \\
\hline & Total & 266 & 100,0 \\
\hline \multirow{3}{*}{ Marital status } & Married & 139 & 53,1 \\
\hline & Single & 123 & 46,9 \\
\hline & Total & 262 & 100,0 \\
\hline \multirow{4}{*}{ Age } & Between 22-29 & 131 & 49,6 \\
\hline & Between 30-39 & 110 & 41,7 \\
\hline & Over 40 & 23 & 8,7 \\
\hline & Total & 264 & 100,0 \\
\hline \multirow{6}{*}{ Professional seniority } & Between 1-5 years & 148 & 55,6 \\
\hline & Between 6-10 years & 66 & 24,8 \\
\hline & Between $11-15$ years & 27 & 10,2 \\
\hline & Between $16-20$ years & 9 & 3,4 \\
\hline & Over 21 years & 16 & 6,0 \\
\hline & Total & 266 & 100,0 \\
\hline \multirow{4}{*}{ Educational backgroud } & Associate degree & 10 & 3,8 \\
\hline & Undergraduate degree & 240 & 90,9 \\
\hline & Master degree & 14 & 5,3 \\
\hline & Total & 264 & 100,0 \\
\hline
\end{tabular}

When examined Table 1, it can be seen that \%36,1 (N:96) of the participants are female, \%63,9 (N:170) are male. In that case, male participants are the majority. \%53,1 (N:139) of the teacher participants are married and \%46,9 (N:123) are single. The teachers who are between $22-29$ years old consist $\% 49,6(\mathrm{~N}: 131)$, the ones between $39-39$ consist $\% 41,7$ $(\mathrm{N}: 110)$, and the teachers over 40 years old consist $\% 8,7(\mathrm{~N}: 23)$ of total participants. So the majority of the study group are below the age $40(\% 49,6+\% 41,7=91,3)$.

Table 1 shows the rates for the professional seniority variables. They are as follows: \%55,6 of the teachers (N:148) are between 1-5 years of professional seniority, \%24,8 (N:66) are 6-10 years, \%10,2 of the participants (N:27) are 11-15 years, \%3,4 (N:9) are 16-20 years and \%6 (N:16) are over 21 years of the total participants.

According to the educational background variables, \%3,8 (N:10) of the participant teachers have associate degree, \%90,9 (N:240) have undergraduate degree, and \%5,3 (N:14) have master's degree diplomas. So that, the majority of the participant teachers have undergraduate degree diplomas (\%90,9; N:240).

When examined Table 2, the schools that the participant teachers' work at had 1-35 teachers and this number consisted \%83,1 (N:217) and 36-70 teachers consisted \%16,9 (N:44) of all participants. The teachers who graduated from faculty of education consisted $\% 57,7(\mathrm{~N}: 153)$, from faculty of science and arts consisted \%29,8 (N:79) and from other faculties consisted \%12,5 (N:33) of all participant teachers. \%59,2 (N:157) of the participant teachers' schools had normal working hours and \%40,8 (N:108) had dual education.

Table 2 shows that $\% 6,7(\mathrm{~N}: 17)$ of the participants teachers thought they totally agree that they had satisfactory salary, \%18,6 (N:49) agree, \%23,1 (N:61) neither agree nor disagree, \%19,7 (N:52) disagree, \%32,2 (N:85) totally disagree with the idea of satisfactory salary.

$\% 0,8(\mathrm{~N}: 2)$ of the participant teachers were preschool teachers, \%37,1 (N:95) were primary school teachers, \%62,1 $(\mathrm{N}: 159)$ were secondary school teachers. \%50,8 $(\mathrm{N}: 132)$ of the participant teachers had extra duty at another school and $\% 49,2$ (N:128) told that they had no extra duty at other schools. 
Table 2. The distribution of the participant teachers according to different variables in quantitative research process (The number of teachers, faculty, working hours, salary, school type and having duty at another school)

\begin{tabular}{|c|c|c|c|}
\hline & & $\boldsymbol{F}$ & $\%$ \\
\hline \multirow{3}{*}{$\begin{array}{l}\text { The number of } \\
\text { teachers }\end{array}$} & Between 1-35 & 217 & 83,1 \\
\hline & Between 36-70 & 44 & 16,9 \\
\hline & Total & 261 & 100,0 \\
\hline \multirow{4}{*}{ Faculty } & Education & 153 & 57,7 \\
\hline & Arts and Sciences & 79 & 29,8 \\
\hline & Other & 33 & 12,5 \\
\hline & Total & 265 & 100,0 \\
\hline \multirow{3}{*}{ Working hours } & Full time & 157 & 59,2 \\
\hline & $\begin{array}{l}\text { Double shift schools (in the mornings or in the } \\
\text { evenings) }\end{array}$ & 108 & 40,8 \\
\hline & Total & 265 & 100,0 \\
\hline \multirow{6}{*}{ Enough salary } & Totally agree & 17 & 6,4 \\
\hline & Agree & 49 & 18,6 \\
\hline & Neither Disagree nor agree & 61 & 23,1 \\
\hline & Disagree & 52 & 19,7 \\
\hline & Totally disagree & 85 & 32,2 \\
\hline & Total & 264 & 100,0 \\
\hline \multirow{4}{*}{ School type } & Preschool & 2 &, 8 \\
\hline & Primary school & 95 & 37,1 \\
\hline & Secondary school & 159 & 62,1 \\
\hline & Total & 256 & 100,0 \\
\hline \multirow{3}{*}{$\begin{array}{l}\text { Having duty at } \\
\text { another school }\end{array}$} & Yes & 132 & 50,8 \\
\hline & No & 128 & 49,2 \\
\hline & Total & 260 & 100,0 \\
\hline
\end{tabular}

For the qualitative part of the research, 14 teachers were included in the research and the characteristics of these participants were shown at Table 3.

Table 3. Characteristics of the participant teachers

\begin{tabular}{|c|c|c|c|}
\hline & $\mathrm{N}$ & & $\mathrm{N}$ \\
\hline Sex & & $\begin{array}{l}\text { Professional } \\
\text { (years) }\end{array}$ & \\
\hline Female & 9 & $6-9$ & 9 \\
\hline \multirow[t]{3}{*}{ Male } & 5 & $10-15$ & 3 \\
\hline & & $16-19$ & - \\
\hline & & $20-25$ & 2 \\
\hline Age & & Branch & \\
\hline $30-35$ & 9 & English & 6 \\
\hline $36-40$ & 2 & Science & 1 \\
\hline $41-45$ & 2 & Classroom teacher & 2 \\
\hline \multirow[t]{4}{*}{$46-50$} & 1 & Philosophy & 1 \\
\hline & & Turkish language and & \\
\hline & & literature & 1 \\
\hline & & Physological Councelling & \\
\hline
\end{tabular}

For the qualitative part of the research, 14 teachers with different branches were included. 9 of them are female, 5 of them are male. 9 of the participant teachers were between 30-35 years old, 2 of them were between 36-40 years old, 2 of them were between 41-45 years old, 1 of them was between 46-50 years old. 9 teachers had between 6-9 years of professional seniority, 3 of them had between 10-15 years of professional seniority, and 2 of them had between 20-25 years of Professional seniority. 6 of the teachers were English teachers, 1 was science teacher, 2 of them were classroom teachers, 1 was philosophy teacher, 1 was Turkish language and literature teacher and 3 of them were psychological counselling teachers.

\section{Data Gathering Tools}

For the quantitative part of the study, "Emotional Labour Behaviors Scale" which was adapted to measure the teachers" emotional labour behaviors by Kaya (2009) was used. It included 2 subdimensions and 10 items. These subdimensions are "Obeying the emotional behavior rules" and "Monitoring the emotions behaviour". Emotional labour behaviors scale is a five point likert scale. Cronbach' Alpha reliability coefficient of the scale is .91 . This rate shows that the scale 
is reliable at high level. In social sciences the values over .60 are accepted as reliable (Can, 2014).

For the qualitative part of the study, the semi structured interview form was prepared by the researchers. Including more than one researcher, laying the research process barely, keeping the raw data and approval of the collected data meet the reliability criteria (Yıldırım ve Şimşek, 2008). Marvasti (2004) explained the reliability as getting the same results of a research by different researchers. For the quantitative research, 14 teachers from different branches were asked the reasons of differences in emotional labour behaviors and suggestions related to the differences

\section{The Data Analysis}

For the quantitative part of the research, in order to measure the emotional labour behaviors of the teachers, descriptive analysis (percentage, arithmetic means, frequency, standart deviation) and to find out the differences between the variables, t-test, ANOVA tests were used ( $p>0.5$ value is statistically significant).

For the qualitative part of the research, content analysis was used to analyse data obtained from the teacher opinions. During the analysis the researchers described themes and subthemes. Following the analysis, the qualitativedata are analysed in depth and categorized.

\section{Findings and Comments}

In this part, the level of the emotional labour behaviors of the teachers, the significant differences, the reasons for the differences and possible solutions were presented.

The level of the emotional labour behaviour levels, arithmetic means and standard deviation values were presented in Table 4.

Table 4. The descriptive statistics related to the teachers emotional labour behaviors

\begin{tabular}{llllll}
$\begin{array}{l}\text { Sub dimensions } \\
\begin{array}{l}\text { Emotional behaviors /Obeying } \\
\text { emotional behavior rules behavior }\end{array}\end{array}$ & $\mathbf{N}$ & $\mathbf{X}$ & ss & Level \\
\hline
\end{tabular}

Emotional labour behavior

Monitoring the emotions behavior

$\begin{array}{lllll} & 266 & 3,71 & , 90 & \text { High } \\ \text { Emotional Labour behaviors in total } & \mathbf{2 6 6} & \mathbf{3 , 8 5} & \mathbf{, 7 8} & \text { High }\end{array}$

Table4 shows that the emotional labour behaviors of the teachers are at high level. $(\mathrm{X}=3,85)$. First subdimension of the emotional labour behavior scale is Obeying the emotional behavior rules and its level is at high $(\mathrm{X}=3,98)$, monitoring the emotions behavior subdimension is at high level $(3,71)$, too.

Table 5. T-Test results of the variable differences related to the teachers emotional labour behaviors

\begin{tabular}{|c|c|c|c|c|c|c|}
\hline & & $\mathbf{N}$ & $\mathbf{X}$ & SS & $\mathbf{t}$ & $\mathbf{p}$ \\
\hline \multirow{2}{*}{ Sex } & Female & 96 & 3,78 & ,73 & \multirow{2}{*}{-1.061} & \multirow{2}{*}{,29 } \\
\hline & Male & 170 & 3,89 & 81 & & \\
\hline \multirow{3}{*}{ Marital status } & Married & 139 & 3,84 & ,78 & \multirow{3}{*}{-.174} & \multirow{3}{*}{,86 } \\
\hline & Single & 123 & 3,85 &, 80 & & \\
\hline & Between & & & & & \\
\hline \multirow[t]{2}{*}{ Number of teachers } & $0-35$ & 217 & 3,80 &, 80 & \multirow[t]{2}{*}{-2.336} & \multirow[t]{2}{*}{, $02 *$} \\
\hline & $36-70$ & 44 & 4,10 & 67 & & \\
\hline \multirow{2}{*}{ Working hours } & Normal & 157 & 4,0 & 66 & \multirow{2}{*}{4.303} & \multirow{2}{*}{, $00 *$} \\
\hline & Double shift & 108 & 3,6 &, 88 & & \\
\hline \multirow{2}{*}{ Having extra duty at another school } & Yes & 132 & 3,75 &, 81 & \multirow{2}{*}{-1.934} & \multirow{2}{*}{, $05 *$} \\
\hline & No & 128 & 3,94 & ,75 & & \\
\hline
\end{tabular}

P.S. Statistically significant value is $* \mathrm{p} \leq .05$.

When Table 5 examined, the findings show that the statistically significant difference between the number of the teachers and working hours was found $(\mathrm{p} \leq .05)$, but there was no statistically significant difference between having extra duty at another school, marital status and sex variables.

When examined the number of the teachers, the statistically significant difference in the emotional labour behaviors is higher at the schools with $36-70$ teachers $(\bar{X}=4,11)$. The emotional labour behaviors are higher. When examined the working hour variable, there was statistically difference at the teachers' the emotional labour behaviors in terms of full time working $(\bar{X}=4,02)$.

There has been intensive education and instruction, limited opportunities, joint usage of the materials at double shifting schools, because of that, there may be emotional labour behaviors of teachers at higher level. 
There was found a statistically significant difference in emotional labour behaviours in terms of having extra duty at another school. The teachers who work extra hours have emotional labour behaviours at higher level than the teachers who don't work at another school.

The age, Professional seniority, educational background, graduation, faculty type, salary satisfaction and school type variables an done way ANOVA analysis are presented in Table 6.

Table 6. ANOVA analysis for the variables: The age, Professional seniority, educational background, graduation, faculty type, salary satisfaction and school type

\begin{tabular}{|c|c|c|c|c|c|c|c|}
\hline & & $\mathbf{N}$ & $\mathbf{X}$ & Ss & $\mathbf{F}$ & $\mathbf{p}$ & The reason of the difference \\
\hline \multirow{4}{*}{ Age } & Between & & & & \multirow{4}{*}{0,593} & \multirow{4}{*}{, 55} & \multirow[t]{4}{*}{ 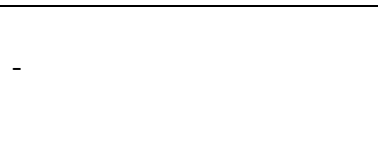 } \\
\hline & $22-29$ & 131 & 3,82 & ,06 & & & \\
\hline & $30-39$ & 110 & 3,83 & 07 & & & \\
\hline & Over 40 & 23 & 4,01 &, 15 & & & \\
\hline \multirow{6}{*}{ Professional seniority } & Between(years) & 148 & 378 & 81 & \multirow{6}{*}{1,048} & \multirow{6}{*}{, 38} & \multirow{6}{*}{-} \\
\hline & $1-5$ & 148 & 3,18 &, 81 & & & \\
\hline & $6-10$ & 66 & 3,89 & ,77 & & & \\
\hline & $11-15$ & 27 & 3,88 & ,78 & & & \\
\hline & $16-20$ & 9 & 4,13 &, 74 & & & \\
\hline & Over 21 & 16 & 4,10 & ,64 & & & \\
\hline \multirow{3}{*}{ Educational background } & Associate degree & 10 & 4,20 &, 16 & \multirow{3}{*}{1,756} & \multirow{3}{*}{, 17} & \multirow{3}{*}{-} \\
\hline & Undergraduate & 240 & 3,83 &, 05 & & & \\
\hline & Master & 14 & 4,10 &, 18 & & & \\
\hline \multirow{3}{*}{ Faculty } & Education & 153 & 3,78 &, 80 & \multirow{3}{*}{8,325} & \multirow{3}{*}{, $00 *$} & \\
\hline & Science and Arts & 79 & 3,77 &, 78 & & & Education \& Other \\
\hline & Other & 33 & 4,36 &, 50 & & & Science and Arts \& Other \\
\hline \multirow{7}{*}{ Salary satisfaction } & Totally agree & & & & \multirow{7}{*}{0,894} & \multirow{7}{*}{,46 } & \multirow[t]{7}{*}{ 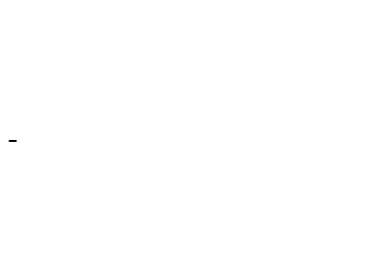 } \\
\hline & Agree & 17 & 3,78 & ,91 & & & \\
\hline & Agree nor disagree & & & & & & \\
\hline & & 49 & 3,75 &, 81 & & & \\
\hline & Disagree & 61 & 3,84 &, 71 & & & \\
\hline & & 52 & 3,77 &, 80 & & & \\
\hline & Totally disagree & 85 & 3,97 & ,79 & & & \\
\hline \multirow{3}{*}{ School type } & Pre school & 2 & 4,75 & 0,34 & \multirow{3}{*}{3,157} & \multirow{3}{*}{, $05 *$} & \multirow{3}{*}{$\begin{array}{l}\text { Primary\& } \\
\text { secondary }\end{array}$} \\
\hline & Primary & 95 & 3,72 & 0,84 & & & \\
\hline & Secondary & 159 & 3,92 & 0,75 & & & \\
\hline
\end{tabular}

P.S.: Statistical difference rate* $\mathrm{p} \leq .05$.

Table6shows there has been found no statistical significant difference at teachers' age, Professional seniority, educational background and graduation, but there has been found statistical significant difference at faculty which they graduate. The scheffe test applied and the result showed that there was significant difference between education and science and arts faculties and other faculties. Teachers who graduated from education and science and arts faculties have emotional labour behaviors at lower level.

There has been found significant difference between the school types $(p \leq .05)$. The arithmetic mean showed that the difference occurred between the primary and secondary schools. The value was higher at secondary schools than the primary schools, so this is for the benefit of the secondary school teachers.

As Table 7 shows the participant teachers explained the reasons for the differences occured about emotional labour behaviors in education faculty graduates as different job definitions, being ready for teaching, the effect of pedagogical lessons, being aware of the professional requirements, accepting the profession as a way of life, learning to teach, reflecting the ideas and emotions. A teacher (T1) expressed the ideas "Teacher candidates prepare themselves to the idea of being a teacher in many ways. They have different equipments for approaching the students by the effect of pedagogical formation". 
Table 7. The analysis of teachers' opinions related to the reasons of emotional labour behavior differences

\begin{tabular}{|c|c|c|}
\hline Variables & Codes & $\mathbf{f}$ \\
\hline $\begin{array}{l}\text { Teachers graduated from education } \\
\text { faculty }\end{array}$ & $\begin{array}{l}\text { Job definition } \\
\text { The idea of being a teacher } \\
\text { Spending time } \\
\text { Pedagogical formation } \\
\text { Professional requirements } \\
\text { Learn to learn } \\
\text { Expressing ideas and thoughts }\end{array}$ & $\begin{array}{l}4 \\
3 \\
3 \\
3 \\
2 \\
2 \\
1\end{array}$ \\
\hline $\begin{array}{l}\text { Primary and Secondary School } \\
\text { teachers }\end{array}$ & $\begin{array}{l}\text { Showing effort and interest } \\
\text { Be controlled } \\
\text { Beginning of the intsruction } \\
\text { Telling about the curriculum } \\
\text { The difference among the ages } \\
\text { Continuity } \\
\text { Adaption } \\
\text { Communication } \\
\text { Different point of views } \\
\text { Responsibilities } \\
\text { Level of behaviours }\end{array}$ & $\begin{array}{l}1 \\
1 \\
2 \\
1 \\
1 \\
1 \\
1 \\
1 \\
3 \\
2 \\
1\end{array}$ \\
\hline $\begin{array}{l}\text { The teachers of the schools that have } \\
\text { less teachers }\end{array}$ & $\begin{array}{l}\text { Occupation } \\
\text { Sincere relationships, communication } \\
\text { Expressing him/herself } \\
\text { Sharing } \\
\text { Collaboration } \\
\text { Devotion }\end{array}$ & $\begin{array}{l}1 \\
1 \\
3 \\
2 \\
2 \\
1\end{array}$ \\
\hline $\begin{array}{l}\text { The teachers of double shift } \\
\text { schooling }\end{array}$ & $\begin{array}{l}\text { Time and happiness } \\
\text { Motivation and focusing } \\
\text { The number of students and teachers } \\
\text { Effective usage of the energy } \\
\text { Private life and professional development } \\
\text { Professional burn out and intensity } \\
\text { Negative mental situation }\end{array}$ & $\begin{array}{l}2 \\
1 \\
1 \\
1 \\
3 \\
2 \\
1\end{array}$ \\
\hline
\end{tabular}

The participant teachers explained the differences in emotional labour behaviors at primary schools: showing much interest and effort for the students and profession, being much more controlled, instructions are at the beginning level, different ages of students and lessons.

Besides, teachers emphasized the continuity of education, the effect of internalisingthe students and organization, strong communication thanks to having much time with the students, different approaches towards students, and teachers' taking less responsibilities. One of the teachers (T4) expressed the idea with these sentences: "The continuity of education strengthen the teacher-student relationship and effects the tacher in a positive way.

The reasons for the significant difference in teachers' emotional labour behavior at schools have less number of teachers were identified as follows: teachers' dealing with more duties, more sincere relationships, more sharing and communication, expressing ideas and thoughts comfortably, collaborative environment, and saving much more time for the students. A teacher (T2) expressed ideas with this sentence: "The communication and collaboration are very strong at the schools with less teachers."

The teachers of the schools with double shift showed emotional labour behavior in significantly different level. They explained the reasons as follows: the working time and teacher happiness have inverse proportion. Lunch time break has negative effect on motivation and concentration. There are increasing number of teachers and students at double shift schools and this negatively causes the effective usage of energy in shorter time. Longer working time causes the limitation of private life and professional development and burn out levels.

Another teacher (T7) explains the reason like that: "the longer working time effects the teachers' mental health negatively." 
Table 8. Teachers' solution suggestions for strengthening the emotional labour behaviours

\begin{tabular}{llc}
\hline & Codes & F \\
\cline { 2 - 2 } & Solving the setting problems & 3 \\
& Providing strong communication & 3 \\
& Regular working hours & 3 \\
& Professional relationships of teachers and school principals & 2 \\
& Inservice trainings & 2 \\
& Strenghtening the communicaiton among teachers-parents and students & 2 \\
Solution suggestions & Providing higher motivation & 1 \\
& Providing organizational culture & 1 \\
& Organising pedagogical and psychological trainings & 1 \\
& Knowing the students better & 1 \\
& Social and cultural activities & 1 \\
& Avoiding demotivating expression & 1 \\
& Provide convenience for teachers with children & 1
\end{tabular}

The participant teachers explained their ideas about solutions to strengthen the emotional labour behaviors. These solutions are Solving the setting problems, providing strong communication, regular working hours, professional relationships of teachers and school principals, inservice trainings, strengthening the communication among teachers-parents and students, providing high motivation, providing organizational culture, organising pedagogical and psychological trainings, knowing the students better, social and cultural activities, avoiding demotivating expression, provide convenience for teachers with children, organising training about emotional labour.

\section{Conclusion and Discussion}

This research has been designed in exploratory mixed methods in order to examine the emotional labour behaviors of the teachers. 266 teachers participated in quantitative part, 14 teachers participated in qualitative part of the research. In quantitative part, the level of emotional labour behaviors of teachers showed and the significant differences among the variables were examined. After that, the suggestions for solutions to strengthen the emotional labour behaviors were asked to the teachers. As a result, the level of the teachers' emotional labour behavior were seen as high. Karakaş, Tösten, Kansu and Aydın (2016) found out the similar result in their research. It has been thought that high level of emotional labour behaviors will contribute positively to realize the organizational aims.

According to Kim's research (2016), the emotional labour behaviors of secondary school teachers in South Korea and Kim explained that this is for the benefit of the organization. However, Barry ve Cassidy (2013) examined the university lecturers' emotional behaviors and found out that if there were serious problems and the emotional labour behaviors were high, this can be evaluated as masking the problems with emotional labour behaviors by the lecturers. In the present study, it has been considered that there hasn't been any masking in the high level of emotional labour behaviors.

It has been found out that there has been lower emotional labour behavior level of teachers at schools that have more crowded teachers. The teachers explained the reasons of this as more Professional duties, weakened sincere relationship in crowded schools, having more difficulties in sharing and collaboration and having more limited time.

The teachers who have extra duties at other schools have weaker emotional labour behaviors than the teachers who haven't. This can be explained as having lower sense of belonging. Because the sense of belonging is very important, otherwise, a teacher who has extra duties at other schools can feel him/herself as a guest. These kinds of teachers may not have the emotional labour behaviours as needed.

The teachers at schools of double shifts have lower emotional labour behaviors than the teachers at full time schools. The reasons have been explained as it has been more difficult to focus and motivate for the teachers at double shift schools. Besides, professional intensity and time limitations may occur.

Double shift schooling has some inconveniences like lower level of sense of belonging and devotion for both teachers and students, complexity in using the equipments and source, weakened interactions. So that, these reasons are the means to effect emotional labour behaviors of teachers negatively.

The other finding of the research shows that the teachers at primary schools have lower emotional labour behaviors than the ones at secondary schools. The reasons of this situation were explained as the difference among the age groups, adoption, the beginning of the educational level, the communication and the contents of the curriculum. But, when considered the truth of the students' need for much interest and emotional labour behaviors. This result can be discussed. 
So that, the emotional labour behaviors of primary and secondary school teachers are advised to be discussed in details.

The solution suggestions of the teachers may be sorted in brief as: strengthening the communication channels, organizing regular working hours, Professional relationships of the principals and the teachers, inservice trainings, providing high motivation, avoiding demotivation, knowing the students better, social and cultural activities and strengthening the organizational culture.

As a result of this study, the emotional labour behaviors of the teachers are at high level and can be strengthened, and the reasons of this situation are double shift schooling, crowded schools, disorders, communication problems. In order to strengthen the emotional labour behaviors, effective communication, motivation, professional competences and counselling have important roles.

\section{References}

Ashforth, E. B., \& Humphrey, H. R. (1993). Emotional labor in service roles: The influence of identity. Academy of Management Review, 18(1), 88-115.

Barry, K., \& Cassidy, S. (2013). Emotional Labour in University Lecturers: Considerations for Higher Education Institutions http://usir.salford.ac.uk/35020/1/Emotional\%20Labour\%20in\%20University\%20Lecturers.pdf(accessed 27.08.2016).

Basım, H. N., Beğenirbaş, M., \& Can, Y. R. (2013). Effects of Teacher Personalities on Emotional Exhaustion: Mediating Role of Emotional Labor http://files.eric.ed.gov/fulltext/EJ1017705.pdf (accessed 27.08.2016).

Beğenirbaş, M., \& Meydan, C. H. (2012). The relationship between emotional labour and organizational citizenship: A Research on Teachers. The Journal of Gazi University Faculty of Economics and Administrative Sciences, 14, 159-181.

Brown, E. L. (2011). Emotion Matters. Exploring the Emotional Labour of Teaching (Doctoral Dissertation). http://d-scholarship.pitt.edu/7209/ (accessed 27.08.2016).

Can, A. (2014). Quantitative data analysis with SPSS research process. (2nd ed.). Ankara: Pegem Akademi

Caruth, G. D. (2013). Demystifying Mixed Methods Research Design: A Review of the Literature. Melvana International Journal of Education, 3(2), 112-122.

Chu, K., He, L., \& Murrmann, K. S. (2006). Development and validation of the hospitality emotional laborscale. Tourism Management, 27(6), 1181-1191. https://doi.org/10.1016/j.tourman.2005.12.011

Çukur, C. (2009). The Development of the Teacher Emotional Labor Scale (TELS): Validity and Reliability. http://www.kuyeb.com/pdf/en/63f3227280db33206c473f3769942adcENTAM.pdf ( accessed 27.08.2016).

Dey, I. (1993) Qualitative Data Analysis, London: Routledge. https://doi.org/10.4324/9780203412497

Diefendorff, M. J., Croyle, M., \& Gosserand, H. R. (2005). The dimensionality and antecedents of emotional labor strategies. Journal of Vacational Behaviour, 66(2), 339-357. https://doi.org/10.1016/j.jvb.2004.02.001

Greene, J. (2007). Mixed Methods in Social Inquiry. California: Jossey-Bass\& Wiley.

Karakaş, A., Tösten, R., \& Kansu, V. (2016). The Effects of Teachers' Emotional Labour Behaviours on Job Satisfaction. Electronic Journal of Social Sciences, 15(56), 177-188. https://doi.org/10.17755/esosder.14708

Kaya, E. (2009). The relationship between teachers' forms of perception of emotional labour behaviors and job satisfaction and job stress. Master's Thesis, Maltepe University, İstanbul

Kim, Y. (2016). Emotional Labour and Burnout among Public Middle School Teachers in South Korea. Master Thesishttps://jyx.jyu.fi/dspace/bitstream/handle/123456789/49560/URN:NBN:fi:jyu201604262318.pdf?sequence= 1(accessed 27.08.2016)

Kinman, G., Wray, S., \& Strange, C. (2011). Emotional labour, burnout and job satisfaction in UK teachers: the role of work place social support, Educational Psychology, 31(7), 843-856 https://www.researchgate.net/publication/232968791_Emotional_labour_burnout_and_job_satisfaction_in_UK_tea chers_The_role_of_workplace_social_support (accessed 27.08.2016)

Liu, L. H. (2009). Research on Emotional Labor of Elementary and Middle School Teachers. Master's Thesis, Chongqing: Chongqing University.

Liu, Y. C. (2012). Discussion on Teachers' Emotional Display Rules. Journal of Zhejiang Normal University: Social Sciences, 63, 6-11. 
Marvasti, A. B. (2004). Qualitative research in sociology. London: Sage Publications Ltd. https://doi.org/10.4135/9781849209700

Morris, J. A., \& Feldman, D. C. (1996). The Dimensions, Antecedents and Consequences of Emotional Labor. Academy of Management Review, 21, 986-1010.

Robbins, S. P. (2005). Essentials of organizational behavior. Translated by: A. Parsayan \& S.M. Aarabi. CulturalResearch Bureau, Tehran, Eleventh Edition

Teddlie, C., \& Tashakkori, A. (2009). Foundations of Mixed MethodsResearch: Integrating Quantitative and Qualitative Approaches in theSocial and Behavioral Sciences. Los Angeles: Sage.

Verma, G. K., \& Mallick, K. (2005). Researching education: Perspectives and techniques. London: FalmerPress.

Xu, Y. X. (2012). Studies on Emotional Labor Strategy of Secondary School Teachers and Its Relationship with Teaching Efficacy and Job Burnout. Master's Thesis, Wuhan: Hubei University

Ye, M. L., \& Chen, Y. (2015). A Literature Review on Teachers' Emotional Labor. Creative Education, 6, 2232-2240. https://doi.org/10.4236/ce.2015.620230

Yıldırım, A., \& Şimşek, H. (2008). Qualitative Research Techniques in Social Sciences. Ankara: Seçkin Publications.

\section{Copyrights}

Copyright for this article is retained by the author(s), with first publication rights granted to the journal.

This is an open-access article distributed under the terms and conditions of the Creative Commons Attribution license which permits unrestricted use, distribution, and reproduction in any medium, provided the original work is properly cited. 